\title{
CYTOTOXIC ACTIVITY AND PHYSICOCHEMICAL PROPERTIES OF GENDARUSIN A-E COMPOUNDS ON ESTROGEN ALFA RECEPTORS (2JF9)
}

\author{
Yen Yen Ari Indrawijaya ${ }^{1 *}$, Nur Ika Octavia ${ }^{1}$, Roihatul Mutiah ${ }^{1}$, Weka Sidha Bhagawan ${ }^{1}$, \\ Burhan Ma'arif ${ }^{1}$
}

\author{
${ }^{1}$ Department of Pharmacy, Faculty of Medicine and Health Sciences, UIN Maulana Malik Ibrahim Malang, East \\ Java, Indonesia \\ *Corresponding author: yenyen.pharmacist@gmail.com
}

\begin{abstract}
Estrogen Alfa (ER $)$ is a receptor used as the main marker to identify the presence of tumors in the breast.compounds Gendarusin A-E have anticancer activity by inhibiting the poliferation of cancer cells and inducing apoptosis. The purpose of this research are to predict the cytotoxic activity, physicochemical properties, and toxicity of the gendarusin A-E compound. The predictions of physicochemical properties were tested in compliance with the Five Lipinski Rules and the results of the ADME process (absorption, distribution, metabolism, and excretion) using the application pkCSM Online tool. Prediction of cytotoxic activity using Molegro Virtual Docker (MVD) by validating receptors and molecular docking. Cancer receptor protein used in Estrogen Alfa with PDB code 2JF9. Toxicity prediction using the Protox II Online tool. The results of this study indicate that the Gendarusin A-E compound didn't completed the Five Lipinski Rules. Gendarusin A-E compounds had activity against receptors Estrogen Alpha which is shown by the results of RMSD $<2$ and Gendarusin A compounds had the smallest Rerank Score of -70.9817 compared to other compounds. Gendarusin B compound had the highest LD50 $1212 \mathrm{mg} / \mathrm{kg}$ and classified in grade 4.
\end{abstract}

Keywords: Gendarusin A-E, Breast Cancer, Alfa Estrogen (ER $\alpha$ ), Cytotoxic Activity, Molecular Docking

\section{INTRODUCTION}

Breast cancer is one type of tumor that grows in breast tissue such as: mammary glands, milk ducts, fat tissue, and connective tissue in the breast [1]. Cancer prevalence is based on Basic Health Research [2] of 1.4 per 1000 occupations and is among the most common causes of death under cardiovascular disease. Chemotherapy and radiotherapy are the most effective treatment for cancer metastasis and non-metastasis [3]). The most commonly used breast cancer drug is Tamoxifen but it has side effects that cause cervical cancer in long-term use. Therefore, it is necessary to develop new drugs as breast anticancer using natural ingredients. The initial way to find out the activities of a plant quickly and does not require expensive costs is to use the method In Silico Molecular (Docking). This method is used to predict whether the chemical content in a plant has anticancer activity by comparing with compounds whose effects are known as 
anticancer [4]. Plants that have the potential to be anticancer are gandarusa (Justicia gendarussa). Gandarusa has activity as cervical anticancer on Hela cells and colon anticancer on HT-29 cells [5]. This plant contains a flavonoid compound which has been isolated, namely gendarusin $A-E$. This compound has anticancer activity which inhibits the proliferation of cancer cells by inhibiting the cell cycle and inducing apoptosis [6]. Breast cancer has receptors, one type of receptor is Estrogen Alfa (ER $\alpha$ ) which is antagonistic (inhibits the growth of cancer cells). This receptor is the main marker to identify the presence of tumors in breast tissue [7]. In silico test is done by connecting the flavonoid compound structure (Gendarusin A-E) against the breast cancer receptors (Estrogen Alfa). Based on these descriptions, this research needs to be done to develop new drugs as breast anticancer by knowing the physicochemical properties using apps pkCSM Online Tools and Basic of Five Lipinski Rules, cytotoxic activity with the interaction between multiple ligands to the receptor, and toxicity using Protox II Online Tool to get LD50 value.

\section{MATERIAL AND METHOD}

\section{Materials}

Chem Bio Draw Ultra12.0, Bio Chem 3D Ultra 12.0, Molegro Virtual Docker 6.0 (Molegro ApS), pkCSM Online Tool, and Protox II Online Tool. The structure of the gedarusin A-E compound and the three-dimensional structure of the receptor Estrogen Alpha (ER $\alpha)$.

\section{Study Design}

ER $\alpha$ PDB code: 2JF9 downloaded from the Protein Data Bank (https://www.rcsb.org/).The SMILES code is downloaded from the SMILES Translator Program (https://cactus.nci.nih.gov/translate/).

\section{Prediction of Physicochemical Properties and Toxicity}

Prediction of Physicochemical Properties and Toxicity using SMILES code and pkCSM Online Tool, then predicted based on the Five Lipinski law. As for toxicity, use the Protox II Online Tool and classify it into the toxicity class.

\section{Docking and Amino Acid Analysis}

Docking and amino acid analysis can be done using the Molegro Virtual Docker program, and all stages use 3D image forms. There are several steps to the docking process, namely: (1). 
Download receptors from the Protein Data Bank website. The receptors that are downloaded must contain ligands. (2). Adding $\mathrm{H}$ atoms to the receptor (because the receptor downloaded is removed) and fixing the receptor protein downloaded, if there are errors / deficiencies of amino acids present. This stage is usually done automatically by a computer program. (3). Detection of position at the receptor, where the drug will be bound (interact). These arecavitiesin the receptor structure. (4). Put the 3D structure of the compound into the selected hole. There are several ways to put the structure of a compound in a hole, in the Molegro Virtual Docker program it is done by "allign" which is to attach three atoms of a compound to the same three atoms on a ligand in the receptor. The selected atoms are generally the atoms in the pharmacophore group. (5). Look at the picture (view) the position of compounds in receptor holes (cavities). There are several pictures to look at the environment of compounds, including: hydrophobic picture, to see the hydrophobic environment of a compound, an electronic picture, to see the electronic environment of a compound, and a picture of the $\mathrm{H}$ bonding of compounds and receptors. Amino acids involved in the process of drug-receptor interactions and pharmacophore groups can be seen from the picture of the $\mathrm{H}$ bonds of compounds and receptors. (6). Docking compounds at the receptor, which is done automatically with the Molegro Virtual Docker program. Things that need to be considered in this process are the selection of the docking compound and the cavity where the drug will interact. The parameters measured in the docking process are the energy values involved, in the form of MolDock Score, Rerank Score, and H bond, and RMSD (Root Mean Square Deviation). To measure the strength of drug-receptor binding, a parameter often used is the Rerank Score [8].

\section{RESULT AND DISCUSSION}

\section{Prediction of Physicochemical Properties and Toxicity}

Prediction results of physicochemical properties using pkCSM Online Tool compound $\mathrm{AE}$ gendarusin none meet the criteria of Five Lipinski Law BM <500, $\log \mathrm{P}<5$, Torsion 0-15, $\mathrm{H}$ Bond Acceptor <10, H Bond Donor <5, and PSA <140. Based on these results it can be seen that the compound Gendarusin A-E does not meet Lipinski's Law which means it has low absorption and permeability [9]. Table 1 shows the predicted results of physicochemical properties and toxicity. 
Toxicity prediction results show that Gendarusin A-E compounds are classified as class 4 with susceptible LDvalues50 566-1213 which means less toxic, the higher the LDvalue50, the lower the toxicity. If a compound is classified as class 4 it means that it shows relatively low toxicity [10]. Based on table 1, compounds Gendarusin A, C, D, E cause toxicity to bacteria while Gendarusin B does not. Gendarusin AE does not cause toxicity to the liver and sensitivity to the skin.

\section{Validation of Estrogen Alfa Receptor}

Validation is performed using ValrogenMolegro Virtual Docker 6.0 by docking back native ligands on receptor holes resulting from the receptor validation process, namely the RMSD (Root Mean Square Devitiation) value with an ideal value $<2 \AA$ [11]. The results of receptor validation are shown in table 2 and the best positions of ligands and receptors are shown in Figure 1. The results obtained fromreceptors Estrogen Alfa Chain A have an ideal RMSD value of 0.81054 .

In Figure 2 shows the hydrogen bonds and steric bonds that occur between amino acids and ligands. Gendarusin A and D compounds have amino acid residues Asp 351, Glu 380, and Trp 383, gendarusin B Ala 340, Asp 351, Leu 346, Thr 347, and Leu 525, gendarusin C has only one residue, Glu 380, Gendarusin E Leu 525, Asp 351, and Glu 380. While tamoxifen as a comparison does not have active residues, but has an electrostatic interaction Asp 351.

The results of the process docking between the Gendarusin A-E compound and tamoxifen with thereceptor Estrogen Alpha (ER $\alpha$ ) with PDB code 2JF9 have a Rerank Scores of -70.9817 (gendarusin A), -68.9485 (gendarusin B), -67.1363 (gendarusin C), -67.66663 (gendarusin D), -69.6190 (gendarusin E), and -101,287 (tamoxifen) shown in Table 3.

\section{Discussion}

The aim of this study is to predict the physicochemical properties, cytotoxic activity, and toxicity of the gendarusin $\mathrm{AE}$ compound againstreceptors Estrogen Alfa (ER $\alpha)$. Aandarusin $\mathrm{AE}$ compounds do not meet the Five Lipinski legal requirements in the process of predicting physicochemical properties. This means that the five compounds have low absorption and permeability. The provisions of the Five Lipinsk law are molecular weights $<500, \log \mathrm{P}<5$, Torsion can rotate $0-15$, HBA $<10, \mathrm{HBD}<5$, and PSA <140 [9]. Gendarusin A-E compound has an LD50 value between $500-2000$ which is $566-1213 \mathrm{mg} / \mathrm{kg}$ and is included in the toxicity class 
4. Compounds classified in class IV and V show relatively low toxicity, and the higher LD50 value that means the lower toxicity [10].

Prediction of cytotoxic activity is done by docking Gendarusin AE compounds withreceptors Estrogen Alfa (2JF9) which were previously validated by receptors by performing redocking molecularto select the most ideal chain. This chain selection can be seen from the RMSD results obtained in the redocking process. If the RMSD value obtained $<2 \AA$ means the value is ideal [11]. In table 2 ER $\alpha$ (Chain A) has an RMSD value of 0.81054 which shows that chain A has an ideal RMSD compared to others.

In table 3, the Rerank Score of the Gendarusin compound is the smallest value compared to the others, which is $-70,6169$. This indicates that the compound Gendarusin A has a high affinity and approaches the Rerank Score of tamoxifen as a comparison. The smaller the value of the bond energy, the more stable it is. The more stable the ligand and receptor binding, the greater the activity [12]. Gendarusin compounds A, C, D, E have hydrogen bonds with the amino acid Glu 380. In previous studies tamoxifen had a hydrogen bond with amino acids Glu 380 and Arg 394 which could increase its antagonistic activity (13). This shows that the compound Gendarusin also has the same activity as tamoxifen which inhibits the growth of cancer cells.

\section{CONCLUSION}

Gendarusin AE compounds do not meet the Lipinski law of five and have low toxicity. Gendarusin A compound has the lowest Rerank Score compared to others and means the highest activity. Gendarusin compounds have almost the same activity as tamoxifen as indicated by the presence of hydrogen bonds with the amino acid Glu 380.

\section{ACKNOWLEDGMENTS}

Thanks to Prof. Dr. Siswandono, Apt., MS, who has given access to theapplication Molegro Virtual Docker 6.0.

\section{REFERENCES}

[1] Mansjoer, A. 2002. Ascaris. In : Kapita Selekta Medicine. Volume 1, Issue 3. Jakarta: Aesculapius Media FKUI. Pages : 416 - 418.

[2] Depkes RI. 2013. Indonesia Health Profile 2013 . Jakarta: Ministry Health of Republic Indonesia.

[3] Bruce. A., Chabner., Thomas. G., Roberts. Jr. 2005. Chemotherapy and The War On Cancer. Nature Review. Volume 5.

J. Islamic Pharm., an open access journal

ISSN: 2527-6123 
[4] Siswandono., Widiandani, T., Hardjono, S. 2017. Docking and Cytotoxicity Test on Human Breast Cancer Cell Line (T47D) of N- (Allycalbamothioyl)-3-chlorobenzamide an D-(Allycarmothioyl)-3,-4-dichlorobenzamide. Research Journal of Pharmaceutical, Biological and Chemical Sciences. 8(2).

[5] Widiyanti, P., Prajogo, B., Hikmawanti Erni, N,P. 2016. Cytotoxicity of Justicia gendarussa Burm F. Leaf Extracts On Molt-4 Cell. Indonesian Journal of Tropical and Infectious Disease. 6(1).

[6] Achmad. H., Supriatno., Marhamah. Rasmidar. 2014. Anticancer and Antiproliferation Activity of Ethnose Ant Nest(Myrmecodya Pendans) On Human Tongue Cancer Cells Manusia SP-C1. Dentofasial. 13(1): 1-6.

[7] Muchtaridi., Yanuar, A., Megantara, S., Purnomo, H., 2018. Basic In Drug Design. First Edition. Jakarta: Prenadamedia Group.

[8] CLCbio. 2013. Moelgro Virtual Docker User Manual, MVD 2013.6.0 for Windows, Linux, and Mac OS X. Molegro A CLC bio company.

[9] Lipinski, C.R., Lombardo, F., Dominy, B.W. and Feeney, F.J. 1997. Experimental and computational approaches to estimate solubility and permeability in drug discovery and development settings. Advanced Drug Delivery Reviews. 23.3-25.

[10] Supandi, Yeni, Merdekawati, F. 2018. In Silico Study of Pyrazolylaminoquinzolube Toxicity by Lazar, Protox, and Admet Predictor. Journal of Applied Pharmaceutical Science. 8(9): 119-129.

[11] Pratama, R.M. 2016. Moleculer Docking Study of Quinolin Derived Compunds Against Estrogen-a Receptor. Surya Medika Journal. 2(1).

[12] Hardjono, S., Siswodihardjo, S., Pramono, P., Darmanto, W. 2016. Quantitative Structure- Cytotoxic Activity Relationship 1- (Benzoyloxy)urea an Its Derivative. Current Drug Discovery Technologies. 13(2), 101-108.

[13] Setiawati, A., Ruswanto, F.O.D., Yuliani, S.H., Istyastono, E.P. 2014. Anticancer Activity Of Mangosteen Pericarp Dry Extract Against Mcf-7 Breast Cancer Cell Line Through Estrogen Receptor - $\alpha$. Indonesian J.Pharm. 25(119-124). 


\section{J. Islamic Pharm. 2019. 4(1): 56-64}

Table 1. Prediction of Physical and Chemical Properties and Toxicity

\begin{tabular}{|c|c|c|c|c|c|c|c|c|c|c|c|c|}
\hline \multirow[t]{2}{*}{ Compound } & \multicolumn{11}{|c|}{ TParameters of Five Lipinski Rules and Toxicity } & \multirow{2}{*}{$\begin{array}{c}\text { Application } \\
\text { of Five } \\
\text { Lipinski } \\
\text { Rules }\end{array}$} \\
\hline & $\mathbf{A}^{*}$ & B* & $\mathbf{C}^{*}$ & $\mathbf{D}^{*}$ & $\mathbf{E}^{*}$ & $\mathbf{F}^{*}$ & $\mathrm{G}^{*}$ & $\mathrm{H}^{*}$ & $\mathrm{I}^{*}$ & $\mathrm{~J} * *$ & $\mathrm{~K}^{* *}$ & \\
\hline & 534.47 & $-\overline{1.1152}$ & 3 & 13 & 9 & 213.149 & Yes & No & No & 566 & 4 & No \\
\hline Gendarusin A & & & & & & & & & & & & \\
\hline & 532.498 & 0.16 & 3 & 12 & 8 & 214.720 & No & No & No & 1213 & 4 & No \\
\hline endarusin B & & & & & & & & & & & & \\
\hline & 534.47 & $\overline{-} 1.1152$ & 3 & 13 & 9 & 213.149 & Yes & No & No & 566 & 4 & No \\
\hline Gendarusin C & 534.47 & $\begin{array}{l}- \\
1.1152\end{array}$ & 3 & 13 & 9 & 213.149 & Yes & No & No & 566 & 4 & No \\
\hline Gendarusin D & 534.47 & $\overline{-} 1.1152$ & 3 & 13 & 9 & 213.149 & Yes & No & No & 566 & 4 & No \\
\hline Ge & 371.524 & 5.9961 & 8 & 2 & 0 & 168.649 & Yes & No & No & 1190 & 4 & No \\
\hline
\end{tabular}

Table 2. Result of Receptor Validation of $\alpha$-Estrogen (2JF9)

\begin{tabular}{cc}
\hline Receptor (2JF9) & RMSD Score (̊) \\
\hline ER $\alpha($ Chain A) & 0.81054 \\
ER $\alpha($ Chain B) & 58.3341 \\
ER $\alpha($ Chain C) & 58.3149 \\
\hline
\end{tabular}

Table 3. Hydrogen Bonding, Steric Bonding and Rerank Score of Compounds

\begin{tabular}{|c|c|c|c|}
\hline Compound & Hidrogen Bond and Distance (A) & $\begin{array}{l}\text { Steric Compund and Distance } \\
(\AA)\end{array}$ & Rerank Score \\
\hline \multirow[t]{4}{*}{ Gendarusin $\mathrm{A}$} & Asp $351(3,23)$ & Val $355(3,03)$ & $-70,9817$ \\
\hline & Glu $380(3,21 \& 2,97)$ & Leu $354(2,95 \& 3,13)$ & \\
\hline & $\operatorname{Trp} 383(2,67)$ & Glu $380(3,18 \& 3,14)$ & \\
\hline & & Trp $383(3,07)$ & \\
\hline \multirow[t]{5}{*}{ Gendarusin B } & Ala $340(2,71)$ & Leu $525(2,91 ; 2,87 ; 3,18 ; 3,15)$ & $-68,9485$ \\
\hline & Asp $351(2,52)$ & Thr $347(3,01 \& 2,45)$ & \\
\hline & Leu $346(2,72)$ & Leu $346(3,09)$ & \\
\hline & Thr $347(2,52)$ & Ala $350(2,87)$ & \\
\hline & Leu $525(3,06)$ & Met $343(3,01 \& 2,45)$ & \\
\hline Gendarusin $\mathrm{C}$ & Glu $380(3,37)$ & Leu $525(3,16)$ & $-67,1363$ \\
\hline
\end{tabular}

J. Islamic Pharm., an open access journal

ISSN: 2527-6123 


\begin{tabular}{|c|c|c|c|}
\hline \multirow{5}{*}{ Gendarusin D } & & Leu $354(2,86 \& 3,18)$ & \multirow{5}{*}{$-67,6663$} \\
\hline & & $\operatorname{Trp} 383(2,84 \& 3,01)$ & \\
\hline & Asp $351(3,22)$ & Val $355(2,93)$ & \\
\hline & Trp $383(2,99)$ & Leu $354(3,18 \& 2,77)$ & \\
\hline & Glu $380(2,70 ; 2,90 ; 3,26 ; 3,36)$ & Asp $351(3,02)$ & \\
\hline \multirow{5}{*}{ Gendarusin E } & & Met $522(3,19)$ & \multirow{5}{*}{$-69,6190$} \\
\hline & & $\operatorname{Trp} 383(3,16 ; 2,80 ; 3,16)$ & \\
\hline & Leu $525(3,02)$ & Asp $351(3,07)$ & \\
\hline & Asp $351(2,60)$ & Trp $383(3,09 ; 3,08 ; 2,85 ; 3,13)$ & \\
\hline & Glu $380(3,30)$ & & \\
\hline Tamoxifen & - & Phe $404(3,18)$ & $-101,287$ \\
\hline
\end{tabular}

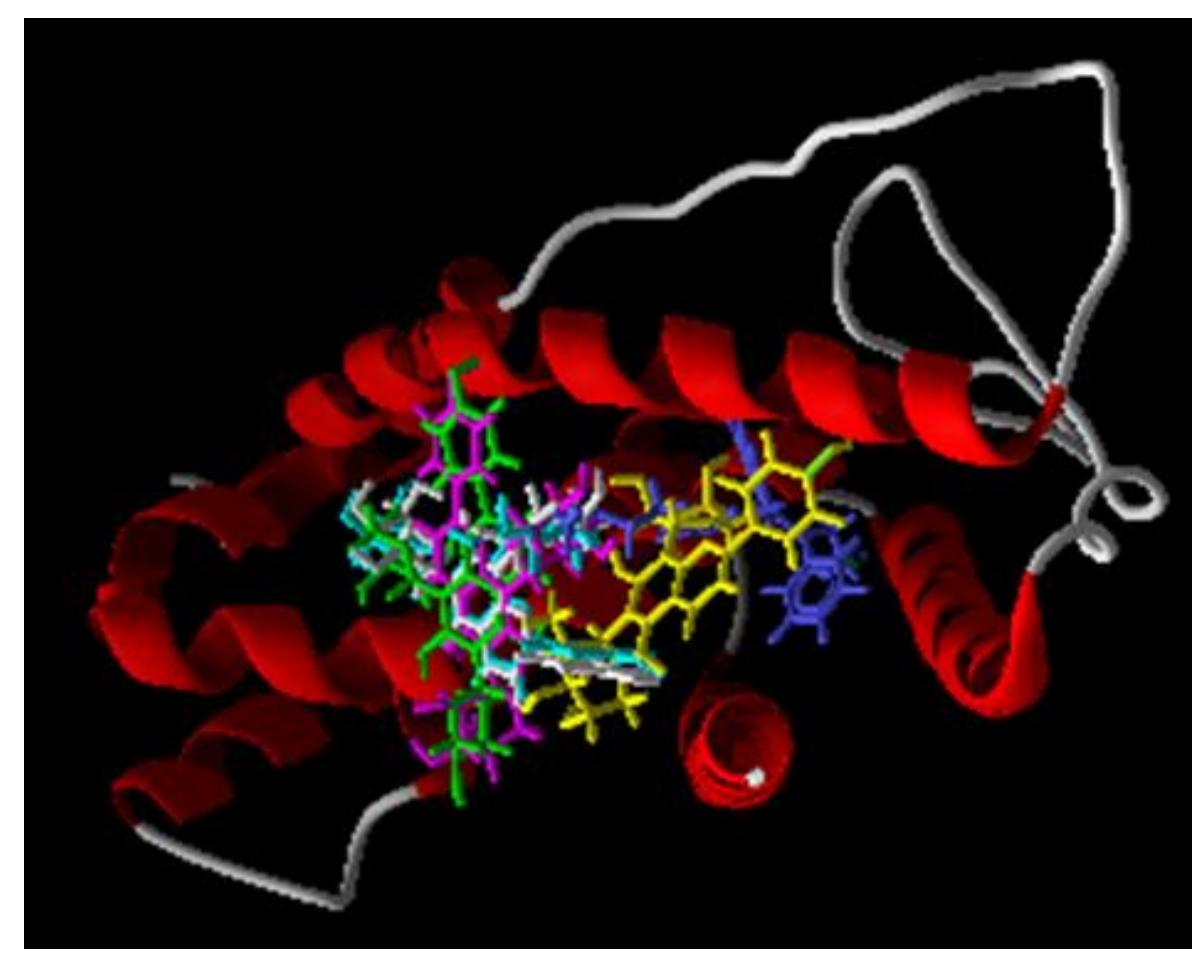

Figure 1. Two dimensional interaction between Gendarusin A-E and Estrogen Chain A (Red: Protein; Blue: original ligand; green: Gendarusin A; Yellow: Gendarusin B; Light blue: Gendarusin C; Purple: Gendarusin D; Gray: Gendarusin F) 

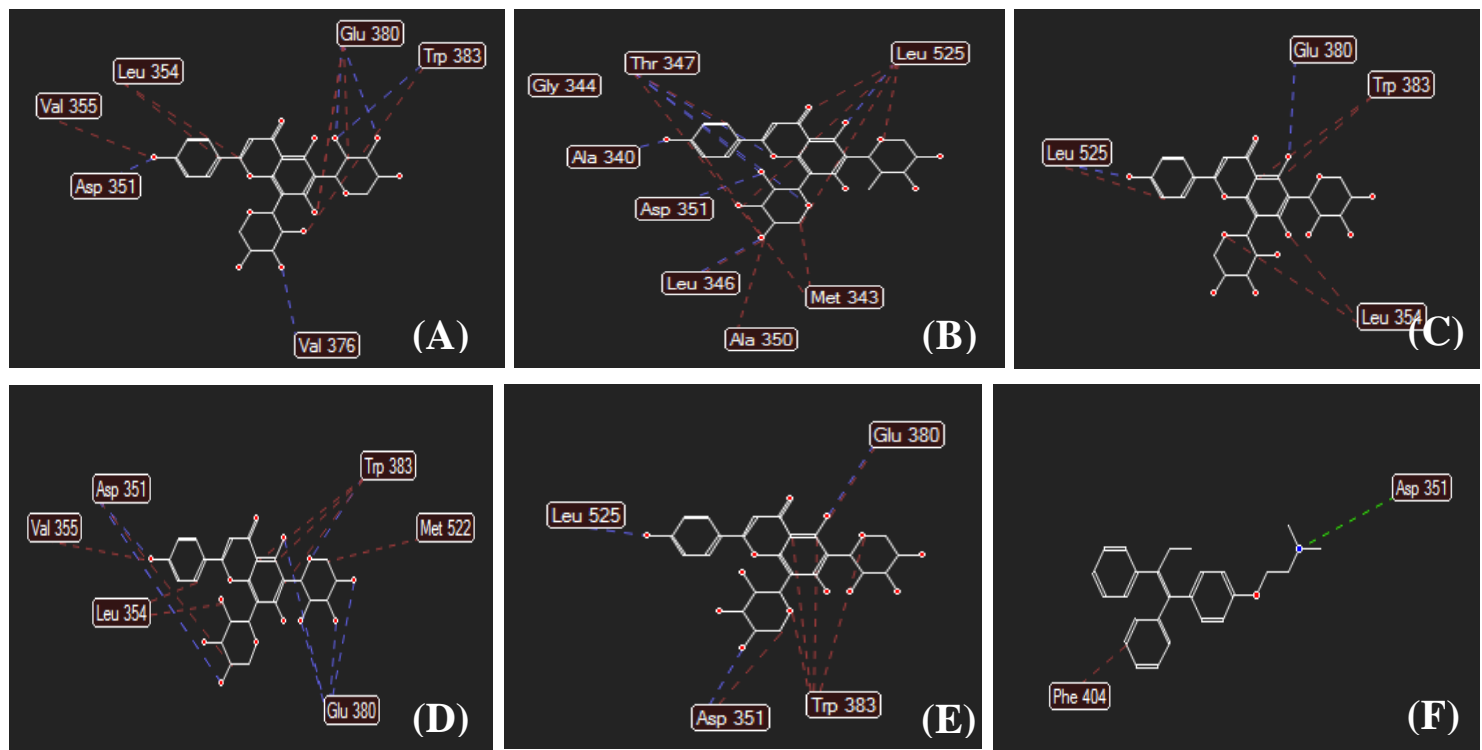

Figure 2. The two-dimensional form of hydrogen bonds Gendarusin A (A), gendarusin B (B), gendarusin $C(C)$, gendarusin $D(D)$, gendarusin $E(E)$, and tamoxifen $(F)$ in the Estrogen Alpha receptor $(\mathrm{ER} \alpha)$ with the code 2JF9 PDB. The blue lines show as hydrogen bonds, red lines as steric bonds, and green lines as electrostatic interactions. 